\title{
Mit fjerne indre
}

Af Ursula AndKjer Olsen

Dette uddrag af digtet "Mit fjerne indre" er laint fra digtsamlingen Det 3. årtusindes hjerte (2012) af Ursula Andkjar Olsen udgivet af Gyldendal. For dette vark modtog Ursula Andkjar Olsen Montanas litteraturpris $2012 \mathrm{gg}$ blev også pramieret af Statens Kunstfond 2013. 
Målet er, at intet dyr i skoven kan lugte mit tab, kan lugte mit nederlag.

Målet er, at RED ikke kan lugtes af dyrene i skoven.

F.eks.

at busken ikke kan lugtes $i$ haven

at reden ikke kan lugtes $i$ busken

at agget ikke kan lugtes $i$ reden

at skoven ikke kan lugtes $i$ agget, og døden ikke.

Målet er at svække ethvert duftspor. Det vil koste mig min sejrs duft. 
Målet er, at al min smerte er et fantom, intet virkeligt har forårsaget den, det er den eneste realistiske smerteudryddelse, der gives.

Jeg tror på det lunkne i menneskets natur. Nej. Jeg tror på det kolde i menneskets natur. 
Viljen til ikke at være offer er samtidig modvilje mod at se overmagten som det, den er: overmagten. Målet er at levere offeret så finpudset og bagbundet som muligt allerinderst i mit fjerne indre. Hvor ingen kan lugte det. 
Hvis jeg bliver begravet levende, hvorfor skulle jeg så prøve at bevare roen? Nogen kunne høre min panik og fryde sig.

Målet er at kunne gøre fortrængningens arbejde, imens du kærtegner min krop.

Er målet at kunne gøre fortrængningens arbejde, selv imens du kærtegner min krop.

Målet er, at min angst ikke kan lugtes. 
Når jeg skal tortureres, så vil jeg synge,

det skal holde dem ude, jeg gik mig ud, jeg

drømte mig, det uvirkelige ved mig skal

stå lysende klart, en sommerdag, lysende, drøm i nat,

lysende.

Intet kan nå mig. 
Viljen til ikke at have indgange, at undgå steder, hvor ydmygelser og overrumplinger finder sted.

Hvad angår blodbanen, det ikke at ville have infrastruktur, det er det samme, solvogn og månevogn kører, ved den mindste berøring udefra, transporterer skinnende, blanke ydmygelser rundt i korpus, og abrakadabra ud i hver en skrigende afkrog.

Jeg bruger dyre dråber, vredens sved, tablet, pastil, salve. Balsam. Jeg bruger tre poser til en kande koma.

Jeg sætter en sten for hulens åbning, ingen kommer ud, ingen kommer ind, intet skal igen opstå, navnet, den kniv i ryggen skal

skal aldrig mere slippe igennem mit paranoialegeme.

Jeg skal være fremdeles ubeskrevet. 
Organet som enten offer eller hersker. I den pågxldende enhed.

Navnet som enten flue eller edderkop i det pågældende spind. 